\title{
THE LIFE OF TRADITIONAL DEMONOLOGICAL LEGENDS IN CONTEMPORARY URBAN UKRAINIAN COMMUNITIES
}

\author{
Inna Golovakha-Hicks
}

\begin{abstract}
In contemporary Ukrainian agrarian and urban folk communities, demonological beliefs are as popular and vital as they were a century ago. In order to understand their popularity among contemporary urban Ukrainians, we must look closely at traditional agrarian folk communities and their folk beliefs. In cities, demonological prose functions as a set of beliefs and superstitions corresponding to the traditional plots and pagan beliefs of previous generations. In urban communities, traditional plots do not function within artistic communicative events as actively as they do in village communities, due to the specific nature of urban (as opposed to agrarian) folk communities.
\end{abstract}

Key words: contemporary beliefs, mythology, performer, Ukrainian demonology, urban legends

Since my membership in the Young Pioneer Organization, ${ }^{1}$ I have been intrigued by the superstitions and demonological beliefs, which surrounded the Soviet and the then post-Soviet reality. Over the past ten years, while doing fieldwork or working with materials recorded by other scholars, the main thought that has preoccupied my mind has been the extent of non-folklore in the life and art of my informants. The answer is: there is not much of it. Most informants do not even realize how deeply traditional knowledge affects their life; some consciously follow the norms and code of ethical behaviour of folk traditions. Claude Lévi-Strauss has written in his Myth and Meaning,

Since I was a child, I have been bothered by, let's call it the irrational, and have been trying to find an order what is given to us as a disorder [...] If the same absurdity was found to reappear [...], then this was something which was not absolutely absurd; otherwise it would not reappear [...]. Mythical stories are, or seem, arbitrary, meaningless, absurd, yet nevertheless they seem to reappear all over the world. (Lévi-Strauss 1995: 11-12)

The article aims to introduce Ukrainian demonology in the context of its effect upon the minds and lives of contemporary Ukrainian urbanites. In contempo- 
rary urban Ukrainian folk communities, demonological beliefs are extremely popular. They function primarily as a set of superstitions, reinforced by mass media and oral transmission. Even among the most educated and technicallyminded modern Ukrainian urbanites, ancient beliefs in witches, witchcraft, house demons, dead souls, sorceresses, and their influence on human life, is unbelievably strong. In the summer of 1994, I recorded with Olesya Britsyna a story from female informant (D.I., 24 years of age, secondary education, urban resident) who sold cakes in kiosks at the Kiev food market (optovyi rynok). She and other salespeople told us about their failed efforts to catch the witch who was turning their cakes bad. They were certain that a local witch damaged their food. (It should be mentioned that the average temperature at the market was above $90^{\circ} \mathrm{F}$, and their cakes were not stored in cooler). Such traditional cause-and-consequence thinking is very common among modern Ukrainian urban and rural communities and they often use superstitions and demonological beliefs as a guide for everyday behavior in life-altering situations.

An example of this is the highly popular "death/funeral related" rituals and superstitions in contemporary Ukraine. Death, which leads to the unknown, is surrounded by ancient folk rites and rituals even in modern society. Some of these traditions are unique, while others are amazingly similar across many cultures. Modern Ukrainians preserve the 'connection' between the world of the living and the world of the dead through these traditions and rituals.

The tradition includes, for instance, mirrors covered with cloth, placing money and written messages as funeral goods in the coffin, and extra plates and glasses at the table for the dead soul, also eating at (and leaving food by) the grave. This tradition is widely spread in many cultures.

That food somehow aids the departed is an ancient belief. From the earliest evidences of human behavior, from pyramids to stone tombs in caves, food has been left at the burial place for the sustenance of the dead in their spiritual state. (Thursby 2006: 81)

All these are elements of the ancient tradition of "keeping in touch" with dead ancestors, and at the same time they are a strong component of spiritual life of contemporary urban and rural Ukrainians. Most of these rituals have roots in Slavic paganism, and some mix pagan beliefs with Christian traditions. When analyzing folk rituals and rites surrounding funerals and mourning, we must remember the wish of the people to continue relations with dead relatives, and belief in the possibility of "keeping in touch". Archaic elements of contemporary funeral rituals express an ancient pagan worldview in which birth, marriage and death exist in unity and the world of the dead might be entered and left at any given time. 
One of the most popular ways to "keep in touch" in modern villages and urban communities is through one's dreams. It is the "safest" way to communicate with a dead relative: neither party has any power at the moment of the meeting and warnings come indirectly, through symbolic images interpreted by the bearers of tradition. In most dreams dead relatives, friends or neighbors come to help or warn about something. In some cases they protect or ask for a favor.

Below is a text recorded by Olesya Britsyna and Halyna Dovzhenok in August 2003 in village Bykov, Zhitomirsky region.

I will tell you about my husband. He never wore any underwear. We did not put any on him [to the coffin]. Well [...] some undergarments and a black suit and a pair of new trousers. The following night I saw him in my dream [...] everyone was in their underwear and he stood naked, covering himself with his hands. The next day I bought him underwear. One man died in our village, so I put it in his coffin. And I never dreamt of him again [...] (Potienko Iaryna, born in 1920.)

To compare, here is a fragment of a story published in Kiev's newspaper Fakty in September 2006:

[...] Svetlana was buried at the old cemetery. Little Vanyushka (a very handsome baby) was lying next to her. It seemed that Svetlana was happy that she had given birth; she was smiling in the coffin [...] A few days after the funeral Svetlana's best friend had a dream about her. Svetlana said, "We have a nice room here; it's very big. One thing is bad, though. There are no toys for Vanyushka, he is bored". As it is done in such situations, Maria Vladimirovna bought a lot of toys and children's books and asked the relatives of someone who had recently died to put these in his coffin. Svetlana appeared in someone's dream once more to say thank you and to let us now that they are fine. (Koprovskaia 2006)

The survival of folk demonology and its popularity among villagers is not as surprising as the influence it continues to have on the worldview and behavior of contemporary urban Ukrainians. While collecting contemporary demonological legends in a traditional community, we clearly saw traces of several superstitions and beliefs of our urban contemporaries, which otherwise would seem inexplicable (e.g., belief in supernatural forces even among the most educated part of the population). Our contemporaries are building a mythical reality using television, newspapers, the Internet and the power of traditional knowledge. 
In most articles about personal or natural disasters the first question Ukrainian journalists ask a victim's relatives is, "Did you feel it coming? Were you experiencing any signs from above?" Responses vary, but the characteristic answers are, "I foresaw it in a dream but did not interpret it correctly"; "A bird flew into my window, predicting the death"; "My dead ancestors warned me of an oncoming tragedy"; or "The dog barked all night". We must remember that such answers imply knowledge of the traditional context at a very deep level, and on the part of both sides, because neither the questioner nor the respondent requires an explanation. Both sides must know that, according to traditional beliefs, the dog barks when death is about to occur, birds portend death by flying into a house or hitting a window, etc. This chain of traditional symbols goes back to the belief that demons and dead souls can transform into animals. People thus find such questions natural in everyday conversation. A communicative artistic event arises in the dialogue between a journalist and a witness, and as a result the news article resembles a folklore narrative, its readers forming the audience. As I have written previously,

Slavic folklorists paid more attention to the attainment of full literacy within traditional Ukrainian folk communities than they did to a different change that more strongly affected those communities: most Ukrainian villagers obtained access to television by the 1970s. Today even the poorest family has a television in its house, and this affects the communicative process dramatically. Television probably has a greater influence than books or magazines on the spiritual life of traditional communities. [...] Ukrainian mass media today is one of the principal channels for oral communication and traditional folk knowledge (especially of demonological plots). When Brazilian soap operas became popular in 1994, it was impossible to get any information from villagers while they were on. Village cats, dogs and cows received Brazilian-flavored names, and even the harvest was to some extent neglected. (Golovakha 2006: 237)

There are plenty of examples where mass media sustains traditional demonological belief. Stuttering, epilepsy, and childhood phobias are the three ailments that urban Ukrainians commonly prefer to treat with the help of a witch or sorceress, vorozka (or babka), who uses an egg and a piece of black cloth (a child's head is covered with the black cloth and the sorceress begins to roll an egg around it, whispering 'magic' words (zagovor/zamovlyannya) for $20-40$ minutes.

How do urban "customers" find such folk healers and fortune tellers? Oral transmission plays a significant but not the principal role. Much more influential are advertisements published in popular magazines and daily newspapers 
by white witches (vorozky and znakharky). The same applies to fortune tellers: At least four of Ukrainian television channels regularly advertise fortune tellers and dream interpreters, also Ukrainian newspapers Fakty, Zhizn, and Bulvar (the most popular among 90 per cent of the population) publish advertisements by fortune tellers and dream interpreters on regular basis. Rarely does any magazine or newspaper lack advertisements for gadalka, vorozka, astrolog. In the summer of 1999, I recorded a story from a 30-year-old female construction worker Irina in Kiev who worked in my apartment additional hours each day in order to pay to a vorozka, whose advertisement she had seen on TV and who had promised the return of her husband. The husband had come back for one day (to pick up his things) and left again. This informant, Irina, was certain that the husband's return resulted from the vorozka's actions and never regretted going to her. As Linda Dégh has pointed out,

If the television commercial cannot be considered the cause, it certainly is an indirect, unintended promoter of the kind of irrationality that makes millions of people fanatically use a certain toothpaste and avoid others, or trust the guidance of their horoscope, join social movements and religious cults, chase monsters in the woods, summon spirits, exorcise demons, search for UFOs in the sky, and become well-versed in the legendry of such activities. This view of the world, as in commercials, shrinks the complex problematic to a single isolated problem, only to solve it with a single magic trick. We live in the world of modern legends, modern magic, modern irrationalism. Anyone who does not like them, should turn off the television. (Dégh 1994: 53)

Folklorists still debate over whether Ukrainian mass media sources are true bearers, or merely deliberate commercializers, of traditional knowledge. In terms of witchcraft and traditional worldview, Ukraine today is about the same as it was a hundred years ago, except that written sources (newspapers, magazines, biblical texts) have been adopted by villagers and now function inside their community as a natural, organic component of oral tradition. So far, literacy has not affected dramatically either the functioning of certain genres or the mentality of its bearers over the last century, has led to a special respect toward published sources, and created a new type of folk tradition bearer in the 20th century. The very fact that such references (to books, newspapers, and magazines) are a prestigious part of contemporary folk communication, and that the more educated villagers are considered (by the others) to be the best tellers, shows that folklore has found a way to survive and to function at a time when published sources and mass media seem to occupy the minds and spiritual life of our contemporaries. As Joseph Campbell has pointed out, 
We shall [therefore] have to recognize in our analysis of the myths, legends, and associated rites [...] according not only to the great variety of social systems that have flourished on this planet, but also to the modes of the nature - knowledge that in the course of the millenniums have shaped and reshaped man's image of his world. (Campbell 1993: 23-24)

The contemporary audience in Ukrainian folk communities has a demand for demonological legends, and receives them with greater interest than other folklore genres. Therefore, the study of demonological legends is an ideal starting point for the study of the traditional worldview of their bearers. Texts themselves become a bridge to the traditional mindset of the villagers. While among urban bearers of tradition, demonological knowledge exists as a set of superstitions, mythical beliefs and analogies; in villages they function as fully organized texts, some of which correspond completely to the recordings of the late 19th century. The Ukrainian village today offers a range of demonological plots, and allows the researcher to not only hear the story but also to sense the presence of house demons (domovyk), to converse with the dead souls, to see dragons flying down the chimneys, to feel demonic wind's power (Vykhor) or to experience unknowing demonic forces in the house. All the example texts below are recorded from the residents of village Ploske, Chernihivsky region, during the summer of 1994 by Olesya Britsyna and Inna Golovakha.

[...] He came home, and went to sleep. It's twelve o'clock. The fork whizz! [...] to the middle of the house.[...] The broom - whizz! The trash can - bang! The cup flied through the air! The old man was lying, trembling, "What was all that about? When I came home, there was nothing inside. Who is fighting in my house?" (Britsyna \& Golovakha 2004: 247)

They say there is a flaming snake. They say he is a demonic creature and he is flying through the chimney [...]. Once he flew in and the person got scared, he grabbed this human and pushed it down to the ground, and the person asked, "Who is this, who is choking me?" - And he said, "I am Zmiy Konoplyany. You see." He says, "It's me - Konoplyany, you have to consider me or I will choke you to death." It's what people told me. (Britsyna \& Golovakha 2004: 153)

At 12 or around it, as long as you live, you should not go into the house, you are young, you don't know that, and don't go out of the house either. If it's a little before 12, you glance at your watch if there is fifteen minutes- twenty minutes before 12 [...] just don't go out, it cannot be done, it's the rule of the old people, it's where they live, there is an enemy and it will swing you, that's true [...] The wind will grab you and you will be all lifeless, useless and deadly ill [...] (Britsyna \& Golovakha 2004: 247) 
In order to understand mythological consciousness and the popularity of demonological beliefs among contemporary urban Ukrainians, we must look closely at traditional agrarian folk communities and their folk beliefs. Urban Ukrainians typically have very tight connections with village life. (Most have firstgeneration relatives living in nearby villages; they visit them, eat food from village gardens, and celebrate major events in the village together with their relatives.) As a result, the traditional agrarian mentality influences urban Ukrainians to a greater extent than contemporary urban lifestyles influence the recently urbanized. Unlike the 20th-century idea of industrialization swallowing agricultural traditions, in Ukraine the traditional mentality and lifestyle are dominant in cities as well. As a result, people at all social levels become bearers of traditional knowledge, with education level having little effect on the transmission of folk demonological beliefs. Urban folk communities which are more mobile and open than the traditional, agrarian folk communities are formed by those who are deeply interested in demonological plots and are eager to share them with neighbors, friends, or colleagues. In cities, demonological prose functions as a set of beliefs and superstitions corresponding to the traditional plots and pagan beliefs of previous generations. In urban communities, the traditional plots do not function as part of an artistic communicative event as actively as they do in village communities, due to the specific nature of urban folk communities versus the agrarian community: in the village, the territorial proximity and the similarity of lifestyle and spiritual interests make the community much stronger as a tradition-oriented and tradition-preserving unit. In the city, members of a particular folk community are much more flexible, mobile and influenced by many different factors. For this reason, it is extremely interesting to see how widespread and influential traditional demonological beliefs among contemporary urban Ukrainians are. The political, social, cultural, and daily life of an ordinary urban Ukrainian is explained by members of the community not through natural causes, but through traditional understanding of the way things happen: If your husband has left you, you must look for the white witch who will help you to win him back; if you are frequently sick, you must look for the black witch who is making you sick. People sincerely believe in superhuman (demonic) influences in their lives, and try to protect themselves with the help of traditional knowledge. They have done it for hundreds of years and still do.

[...] Magic used for protection and enhancement of one's private animal husbandry was a means of securing one's current and future financial independence from others, no matter who those 'others' were - fellow villagers or the State [...] Magic was the means of protection. (Kukharenko 2007: 54) 
The wide spread of demonological beliefs among urbanized people tells us that in contemporary Ukraine the connections (spiritual, cultural and economic) between the city and village are very tight, and the traditional agrarian way of living has influenced and continues to influence people's lives more profoundly than urbanization has in traditional communities.

\section{COMMENTS}

${ }^{1}$ A mass youth organization in the Soviet Union, which was active in 1922-1991.

\section{REFERENCES}

Britsyna, Olesya \& Golovakha, Inna 2004. Prosovyi Folklore Sela Ploske na Chernihivshyni:Teksty ta Rozvidky. Kiev: Academy of Sciences of Ukraine.

Campbell, Jerry 1993. Myths to Live by. London: Arkana.

Dégh, Linda 1994. American Folklore and the Mass Media. Bloomington: Indiana University Press.

Golovakha, Inna 2006. Demonology in Contemporary Ukraine: Folklore or 'Postfolklore'. Journal of Folklore Research, Vol. 43, No. 3 (September-December 2006), pp. 219-241.

Koprovskaia, Irina 2006. V obmen na raspisku: mol, pretenzii k bol'nitse ne imeem, vrach predlozhil tysiachu griven $\mathrm{i}$... meshok odezhdy iz sekond-khenda dlia dvukhletnego siroty. (In exchange for the promise not to file complaints against the hospital, the doctor offered 1,000 hryvnias... and a bag of second-hand clothes for a two-year-old orphan). Fakty, 21 September 2006. Available at http://facts.kiev.ua/archive/2006-0921/15863/index.html.

Lévi-Strauss, Claude 1995. Myth and Meaning. New York: Schocken Books.

Kukharenko, Svitlana 2007. Animal Magic: Contemporary Beliefs and Practices in Ukrainian Villages. Folklorica, XII (V), pp. 53-76.

Thursby, Jacqueline S. 2006. Funeral Festivals in America: Rituals for the Living. Lexington: The University Press of Kentucky. 